\title{
NEW POTATO BREEDING CLONES FOR REGIONAL TESTING IN WESTERN TURKEY
}

\author{
Gulsum OZTURK*, Zihin YILDIRIM \\ Ege University, Faculty of Agriculture, Department of Field Crops, Izmir, TURKEY \\ *Corresponding author: gulsum.ozturk@ege.edu.tr
}

Received: 10.08 .2020

\begin{abstract}
Crosses were made between 4 potato genotypes and the registered variety Nif in 2015 . The $F_{1}$ seeds obtained from these crosses were grown in pots in the greenhouse to obtain potato clones. The clones selected were grown in seedbeds in 2016 and clones with high yield and tuber number were selected. Selected clones were grown in the field and selection was applied for high yield and yield components. The results obtained could be summarized as followings:

There were significant variation among the clones and some of them had higher yield than that of the control genotypes. The following 20 clones were selected for the regional yield trials: 3, 21, 184, 185, 194, 195, 196, 202, 204 (Agria $x$ Nif); 89, 90 (6/7 Clone $x$ Nif); 205 (Juwel $x$ Nif) and 153, 159, 160, 163, 164, 174, 176, 177 (Bettina $\mathrm{x}$ Nif).
\end{abstract}

Keywords: Potato breeding, potato clone, selection, yield component, yield trial

\section{INTRODUCTION}

In Turkey 4.7 million tons of potatoes were produced from 144 thousand hectare area with 32.8 tons ha $^{-1}$ average yield. In the Aegean Region 933.075 tons of potatoes were produced from a 26.5 thousand $\mathrm{ha}^{-1}$ planting area. Izmir and Afyonkarahisar provinces produced 367.706 tons and 476.900 tons of potatoes respectively (Anonymous, 2016).

Potato studies have been started in 1927 with the establishment of Sakarya Seed Improvement Station in Turkey (Yildirim and Yildirim, 2002; Yildirim and Ozturk, 2016). Potato breeding work has been started in the Aegean Agricultural Research Institute in the Aegean Region in 1964. Potato breeding studies have been started in the Ege University in 1970 and the first potato variety bred in Turkey was released by this university in 1996 (Yildirim et al., 1998).

A potato breeding program was started by using Andigena type potatoes in the Department of Field Crops of Ege University (Yildirim, 1977). Yildirim and Caliskan (1981) studied various potato introduction from South America and selected some andigena and neotuberosum clones to be used as parents in the crosses. Yildirim et al. (1991) have studied the adaptation capacities of 14 potato breeding clones involving are andigena parent were grown at Bornova, Menemen and Bozdag location in a yield trial and clones with high adaptation were selected. Among the studied clones one promising clone was later released as Nif (101).
Yildirim et al. (1996) has reported that crosses involving R.143 high means for plant height and number of stems. Yilmaz et al. (2014) have crossed some potato clones with commercial varieties in order to obtain potato clones. Bulbul and Caliskan (2014) have studied the yield performances of 48 potato clones at Antalya, Sivas and Gaziantep locations. Kaya et al. (2014) have studied the field performances of potato clones at Erzurum and Bitlis locations and proposed two advanced potato clones as candidate of potato cultivar. Ozkaynak (2020) developed advanced potato clones with PVX resistance from crossings of 16 potato cultivar in Antalya.

Andigena clones selected by Yildirim and Caliskan (1981) had certain advantages over tuberosa group. Especially the registered variety Nif has high number, flower and true seed production and also has high dry matter content. Therefore the purpose of this study was to develop potato breeding clones from crosses of 4 potato cultivars with Nif genotype for regional yield testing.

\section{MATERIALS AND METHODS}

This study has been conducted in the potato seed laboratory; greenhouse, seedbeds and experimental field of the Field Crops Department of the Ege University between 2015 and 2017.

Climatical and soil characteristics of the research area are given in Tables 1 and 2. 
Table 1. Temperature and total precipitation of Bornova county Izmir-Turkey*

\begin{tabular}{lll}
\hline Years/Months & Temperature $\left({ }^{0} \mathrm{C}\right)$ & Total Precipitation $(\mathrm{mm})$ \\
\hline $\mathbf{2 0 1 5}$ & & \\
\hline February & 11.5 & 21.6 \\
March & 13.3 & 163.4 \\
April & 17.0 & 133.3 \\
May & 21.1 & 70.1 \\
June & 25.2 & 57.8 \\
July & 28.1 & 21.0 \\
August & 28.8 & 30.9 \\
\hline $\mathbf{2 0 1 6}$ & & \\
\hline August & 26.8 & 0.4 \\
September & 22.1 & 8.6 \\
October & 16.5 & 0.5 \\
November & 11.2 & 123.8 \\
December & 10.2 & 20.2 \\
\hline 2017 & & \\
\hline January & 3.1 & 233.4 \\
February & 7.4 & 60.0 \\
March & 10.6 & 60.5 \\
April & 13.7 & 14.3 \\
May & 18.5 & 70.4 \\
\hline *: from Bornova Meteorological Station & &
\end{tabular}

Soil of the experimental field is loamy-clay (0-20 7.1-7.6. The soil characteristics of the experimental field depth); clay $(20-30 \mathrm{~cm})$ soil type; rich in calcium with $\mathrm{Ph}$ are shown in Table 2.

Table 2. Soil characteristics of the experimental field

\begin{tabular}{lcc}
\hline Soil characteristics & & Soil Dept. $(\mathbf{c m})$ \\
\hline Physical traits & $\mathbf{0 - 2 0}$ & $\mathbf{2 0 - 4 0}$ \\
\hline Texture & Loamy-clay & Clay-loamy \\
Sand \% & 24.72 & 32.72 \\
Loam \% & 42.72 & 36.72 \\
Clay \% & 32.56 & 30.56 \\
\hline Chemical traits & & 7.60 \\
\hline Ph & 7.10 & 18.64 \\
Calcium \% $\left(\mathrm{CaCO}_{3}\right)$ & 15.46 & 2.15 \\
Organic matter \% & 2.17 & 0.075 \\
Total salt \% & 0.095 & \\
\hline
\end{tabular}

\section{Genetic material}

Genetic material used as parent consisted of four potato genotypes selected in the field trials by Ozturk and
Yildirim (2014). The characteristics of these genotypes are shown in Table 3.

Table 3. Potato genotypes used as parents in the study

\begin{tabular}{|c|c|c|}
\hline Genotype & Origin & Characteristics \\
\hline Agria & Quartes x Sendo & $\begin{array}{l}\text { Medium early-high yielding, yellow flesh, long } \\
\text { oval, total dry matter } 18.9 \% \text { and starch } 13.7 \%\end{array}$ \\
\hline Nif & Cosima x R.143 & $\begin{array}{l}\text { Medium early-high yielding, oval tuber, dry matte } \\
23.4 \% \text { and starch } 16.8 \% \text {, High level flower and fruit } \\
\text { production }\end{array}$ \\
\hline Bettina & Record & $\begin{array}{l}\text { Tuber size uniform, high yielding, oval tuber shape, } \\
\text { cooking consumption }\end{array}$ \\
\hline Clone $6 / 7$ & Merrimack x DTO17 4x-(4x-2x) & $\begin{array}{l}\text { High yielding, flowers and seed production with } \\
\text { FDR mechanism }\end{array}$ \\
\hline Juwel & Record & Early, high yielding, long-oval tuber shape \\
\hline
\end{tabular}




\section{Crossings}

Parents were sown in plastic pots and in also the field at one monthly intervals starting January 2015. Following flowering stems were cut at late afternoon and kept placed in bottles in the laboratory (Figure 1). Flowers were emasculated and then pollinated with the pollen of male parent (Nif). After pollination the stems were kept in the bottles and seeds were obtained from developed and ripened fruits by squeezing in the water.

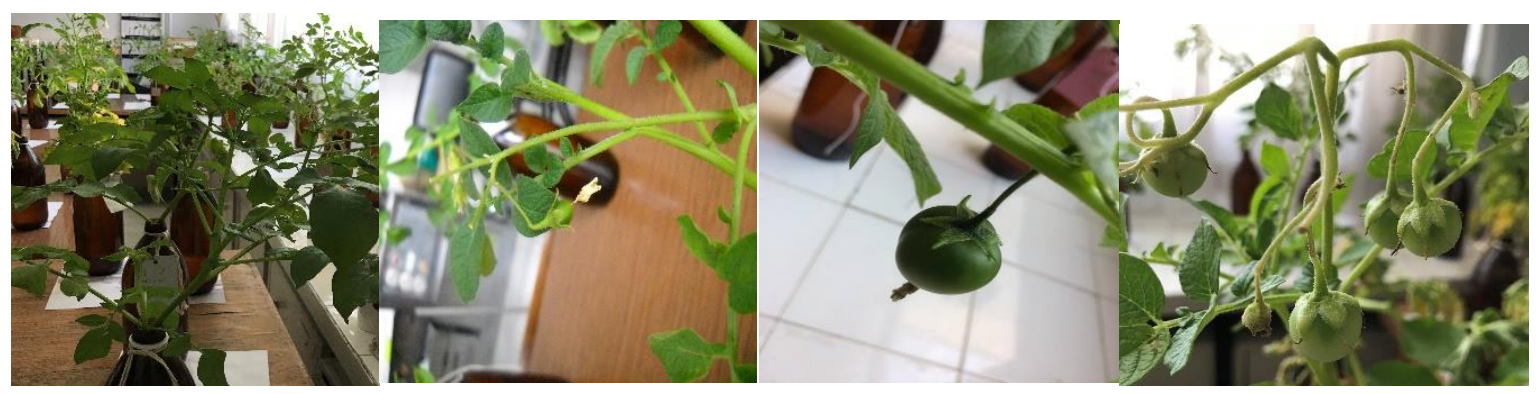

Figure 1. Stems after pollination and fruits developed in the potato laboratory

\section{Growing true potato seeds in greenhouse}

Seeds obtained were sown in plastic vials on December 10, 2015 after breaking dormancy and then transferred to plastic pots. First appearance of seedling was started on December 19-21. Developed seedlings in 3-4 cm height were transferred to plastic pots. A total of 2.500 plants were grown in the greenhouse and observed. The plants developed were harvested in late February by hand and tubers obtained from each plant was numbered as clones.

\section{Growing potato clones in seedbeds}

A total 206 clones and 13 open pollinated clones were sown in seedbeds on August 17, 2016. The observations were done and their yield potentials were evaluated and the selected clones were harvested on December 16, 2016.

\section{Field trial}

Selected clones in the seedbeds and some open pollinated clones of Nif were grown in a field trial arranged in the RCBD with 2 replications in the experimental field in Bornova-Izmir. One single row plots $3 \mathrm{~m}$ long $70 \mathrm{~cm}$ apart and $30 \mathrm{~cm}$ on the row spacing were used. Field trial was planted on February 13, 2017 and harvested on June 28, 2017 by hand.

\section{Cultural practices and measurement of traits}

The standard recommended practice of potato growing in the region were applied during the growing period. Two plants were selected at random in each plot to measure plant characteristics and yield components. During the growing period plant height $(\mathrm{cm})$, stem number and leaf number were measured and expressed as average of two plants.

At the harvest tuber number, single tuber weight $(\mathrm{g})$, plant yield (g) were measured and expressed as average of two plants and total yield of ten plants was recorded as plot yield $(\mathrm{kg})$.

\section{Statistical evaluation}

Data obtained in the field trial were analyzed by the statistical program Totemstat (Acikgoz et al., 2004). The standard analysis of variance technique was used and variation were controlled by the F- test the means of the clones were compared by using the Least Significant Difference (LSD) test as described by Steel and Torrie (1980).

\section{RESULTS AND DISCUSSION}

The results of analysis of variance for plant characteristics and yield components of selected clones and open pollinated clones of Nif grown at the experimental field at Bornova are shown in Table 4. 
Table 4. Means of the plant characteristics and yield components of selected clones and open pollinated clones of Nif measured in the field trial run at experimental field in Bornova, İzmir in 2017.

\begin{tabular}{|c|c|c|c|c|c|c|c|c|}
\hline Clone & Crossing & $\begin{array}{l}\text { Plant height } \\
(\mathrm{cm})\end{array}$ & Stem number & Leaf number & Tuber number & $\begin{array}{l}\text { Single tuber weight } \\
(\mathrm{g})\end{array}$ & Plant yield (g) & $\begin{array}{c}\text { Plot yield } \\
\text { (kg) }\end{array}$ \\
\hline 3 & Agria $x$ Nif & 45.8 & 2,0 & 49.0 & 6.0 & 141.8 & 850.5 & 4.5 \\
\hline 21 & Agria $x$ Nif & 58.5 & 2.0 & 90.8 & 6.8 & 59.1 & 398.3 & 2.9 \\
\hline 27 & Agria $x$ Nif & 51.7 & 2.3 & 44.8 & 5.8 & 49.8 & 285.6 & 2.4 \\
\hline 89 & $\begin{array}{l}\text { Clone } 6 / 7 \quad x \\
\text { Nif }\end{array}$ & 73.0 & 3.3 & 102.0 & 8.0 & 69.3 & 554.8 & 4.3 \\
\hline 90 & $\begin{array}{l}\text { Clone } 6 / 7 \quad x \\
\text { Nif }\end{array}$ & 58.0 & 3.8 & 73.0 & 10.0 & 45.3 & 464.3 & 3.3 \\
\hline 153 & Bettina x Nif & 59.5 & 3.0 & 94.5 & 10.0 & 46.7 & 467.0 & 3,4 \\
\hline 154 & Bettina x Nif & 50.3 & 2.0 & 44.0 & 8.0 & 43.6 & 348.1 & 3.0 \\
\hline 159 & Bettina x Nif & 60.5 & 4.3 & 80.5 & 8.3 & 81.7 & 673.3 & 5.7 \\
\hline 160 & Bettina x Nif & 47.9 & 1.5 & 69.3 & 7.5 & 86.2 & 644.1 & 4.1 \\
\hline 163 & Bettina x Nif & 57.3 & 3.8 & 55.3 & 8.0 & 53.1 & 425.0 & 4.0 \\
\hline 164 & Bettina x Nif & 52.9 & 1.8 & 104.5 & 6.0 & 66.7 & 400.3 & 2.6 \\
\hline 167 & Bettina x Nif & 45.3 & 1.5 & 39.5 & 7.5 & 46.4 & 347.8 & 2.4 \\
\hline 174 & Bettina x Nif & 58.5 & 1.5 & 31.3 & 11.8 & 30.6 & 359.3 & 2.9 \\
\hline 176 & Bettina x Nif & 54.0 & 3.3 & 58.5 & 12.0 & 52.0 & 624.1 & 4.1 \\
\hline 177 & Bettina x Nif & 59.8 & 4.8 & 107.5 & 9.5 & 63.7 & 605.4 & 4.0 \\
\hline 179 & Agria x Nif & 50.3 & 2.3 & 100.8 & 3.0 & 80.4 & 241.2 & 1.8 \\
\hline 184 & Agria x Nif & 57.7 & 1.5 & 64.0 & $\overline{12.5}$ & 64.4 & 805.4 & $\overline{3.7}$ \\
\hline 185 & Agria $x$ Nif & 47.3 & 2.5 & 55.0 & 6.8 & 70.4 & 474.7 & 3.0 \\
\hline 190 & Agria $x$ Nif & 39.8 & 2.8 & 46.5 & 6.0 & 53.6 & 321.2 & 3.1 \\
\hline 194 & Agria $x$ Nif & 48.8 & 2.3 & 62.8 & 6.3 & 106.2 & 615.7 & 3.9 \\
\hline 195 & Agria $x$ Nif & 52.5 & 2.0 & 33.0 & 5.0 & 132.3 & 661.5 & 3.3 \\
\hline 196 & Agria $x$ Nif & 53.8 & 1.5 & 60.8 & 9.3 & 59.0 & 559.5 & 3.6 \\
\hline 202 & Agria $x$ Nif & 52.8 & 1.0 & 55.5 & 7.0 & 72.6 & 508.3 & 2.7 \\
\hline 204 & Agria $x$ Nif & 52.0 & 3.8 & 59.8 & 6.5 & 87.8 & 557.3 & 3.5 \\
\hline 205 & Juwel x Nif & 43.0 & 3.5 & 45.8 & 7.8 & 63.5 & 491.7 & 3.7 \\
\hline 207 & $\begin{array}{l}\text { Open } \\
\text { pollinated }\end{array}$ & 49.5 & 5.3 & 71.3 & 7.0 & 45.9 & 321.5 & 3.0 \\
\hline 208 & $\begin{array}{l}\text { Open } \\
\text { pollinated }\end{array}$ & 34.3 & 1.0 & 23.0 & 5.8 & 41.7 & 228.9 & 2.2 \\
\hline 209 & $\begin{array}{l}\text { Open } \\
\text { pollinated }\end{array}$ & $\underline{28.7}$ & 1.5 & 42.5 & 5.8 & 37.4 & $\underline{205.8}$ & 2.4 \\
\hline 210 & $\begin{array}{l}\text { Open } \\
\text { pollinated }\end{array}$ & 41.9 & 2.0 & 57.3 & 5.5 & 42.3 & 232.6 & 2.4 \\
\hline 211 & $\begin{array}{l}\text { Open } \\
\text { pollinated }\end{array}$ & 31.8 & 1.5 & 63.3 & 5.8 & 65.4 & 376.0 & 3.2 \\
\hline 213 & $\begin{array}{l}\text { Open } \\
\text { pollinated }\end{array}$ & 44.5 & 1.0 & 54.3 & 4.8 & 80.6 & 381.8 & 3.0 \\
\hline 215 & $\begin{array}{l}\text { Open } \\
\text { pollinated }\end{array}$ & 32.9 & 1.0 & $\underline{21.0}$ & 9.8 & $\underline{28.2}$ & 273.6 & 2.4 \\
\hline Nif & Cultivar & 49.3 & 2.0 & 56.5 & 6.0 & 90.8 & 363.0 & 2.8 \\
\hline Bettina & Cultivar & 54.5 & 2.5 & 49.3 & 7.3 & 83.5 & 604.5 & 3.3 \\
\hline & & $\begin{array}{c}\operatorname{LSD}_{(0.05)}: 4.858 \\
\text { F: } 30.355^{* * *}\end{array}$ & $\begin{array}{c}\operatorname{LSD}_{(0.05)} \\
0.494 \\
\mathrm{~F}: 41.802^{* *}\end{array}$ & $\begin{array}{c}\operatorname{LSD}_{(0.05)}: 22.013 \\
\mathrm{~F}: 8.120^{* *}\end{array}$ & $\begin{array}{c}\operatorname{LSD}_{(0.05)}: 0.615 \\
\text { F: } 101,298^{* *}\end{array}$ & $\begin{array}{c}\operatorname{LSD}_{(0.05)}: 10.127 \\
\text { F: } 53.443^{* *}\end{array}$ & $\begin{array}{c}\operatorname{LSD}_{(0.05)} \\
42.435 \\
\text { F: } 126.074^{* *}\end{array}$ & $\begin{array}{c}\operatorname{LSD}_{(0.05)} \\
0.463 \\
\text { F: } 22.831^{* *}\end{array}$ \\
\hline
\end{tabular}

**: significant at the $\mathrm{p} \leq 0.01$ probability level

It could be seen in Table 4 that there was statistically significant variation for plant height $(\mathrm{cm})$, stem number and leaf number among the clones at the $\mathrm{p} \leq 0.01$ level. A large variation for plant height could be observed and 8 clones had high values than that of control. The highest plant height was for clone 89 from the 6/7 clone x Nif cross with $73 \mathrm{~cm}$. The lowest plant height was observed for open pollinated clones 209, 211 and 215 (28.7, 31.8, 32,9 respectively). Yildirim and Caliskan (1981) reported that Andigena clones had high plant height during the spring growing. Andigena clone R.143 one of the parents of Nif so the cross 6/7 clone $\mathrm{x}$ Nif had high plant height.

The highest stem number (5.3) was for clone 207 (open pollinated), clone 177 and clone 159 (4.8 and 4.3) from the Bettina $x$ Nif cross had also high stem number. Low stem numbers (1.0) were for open pollinated clones 208, 213 and 215. Clone 202 had the lowest stem number
(1.0) coming from the Agria $\mathrm{x}$ Nif cross. Yildirim et al. (1988) has reported as high as 11.9 stem number in their studies. This mean was considerable higher than our means.

Clone 177 from (Bettina x Nif) cross had the highest leaf number (107.5). Low leaf numbers were observed for open pollinated clones 215, 208 and 209. Clone 174, 195, 167 and 154 also had low leaf number. Yildirim and Caliskan (1981) stated that leaf number itself could not be sufficient enough to give information about yielding capacity, so it should be considered along with leaf area.

It could also be observed in Table 4 that tuber number, single tuber weight $(\mathrm{g})$, plant yield $(\mathrm{g})$ and plot yield $(\mathrm{kg})$ had highly significant variation. For example clone 184 had the highest mean for tuber number (12.5). This clone was originated from the Agria x Nif cross. Clone 176 
(12.0), clone 174 (11.8) and clone 153 (10.0) from the Bettina $x$ Nif also had high tuber number. Clone 90 from the $6 / 7$ (FDR mechanism) x Nif crossing had also high tuber number (10.0). Cicek (1987) reported that $4 X-2 X$ FDR cross populations had high values for yield components. Clone 6/7 was a selection from these crosses and this clone also had high tuber number. Yildirim and Caliskan (1981) reported high tuber number for Andigena populations. They proposed selection among the Andigena and Neotuberosum populations close to cultural potato forms. In our crossing program Nif variety, a selection from (Cosima x R.143), were used as male parent extensively. This variety had high yield with high level of flower, fruit and seed production. Therefore it was a good male parent in several crossings so we have used it male parent. The lowest tuber number was for clone 179 (3.0) from the Agria x Nif cross. In selection process tuber number should also be considered with plant yield for possible success.

When the mean for single tuber weight (tuber yield plant $^{-1}$ ) were compared it could be seen that clone 3 (141 $\mathrm{g})$, clone 195 (132,3 g) and clone 194 (106.2 g) had the high values. They were selections from the Agria $x$ Nif cross. Simmonds (1966) has reported that single tuber weight was high in the Andigena and Neotuberosum populations as compared to tuberosa group. As it was stated earlier that Nif cultivar was a selection from the cross of Andigena R.143 with Cosima so high single tuber yield could be expected in the clones originated from crosses involving Nif. But clone 174 (30.6 g) from
(Bettina $\mathrm{x}$ Nif) and clone 215 (open pollinated) (28.2 g) had very low means for single tuber weight.

Clone $3(850.5 \mathrm{~g})$ and clone $184(805.4 \mathrm{~g})$ from the Agria x Nif cross had the highest plant yield. Clone 159 $(673.3 \mathrm{~g})$ and clone $160(644.1 \mathrm{~g})$ followed them. Low means such as 241,2 $\mathrm{g}$ (clone 179) and $285.6 \mathrm{~g}$ (clone 27) were obtained for plant yield. Low plant yields were also observed for open pollinated clones 209 (205.8 g), 208 $(228.9 \mathrm{~g})$ and 210 (232.6 g). Yildirim and Caliskan (1981) has reported that suitable selection for tuber yield could be applied among Andigena populations. They selected clones R.143, R.68, R.162 and R.163 to be used as parent in their crosses. Clone R.143 was later used as parent as crossing with Cosima variety and one clone originated from this cross Nif was as registred cultivar.

The highest plot yield was for clone $159(5.7 \mathrm{~kg})$ from the Bettina $x$ Nif cross, clone $3(4.5 \mathrm{~kg})$ from the Agria $\mathrm{x}$ Nif and clone $89(4.3 \mathrm{~kg}$ ) (clone 6/7 x Nif) cross. Clone 179 had the lowest plot yield $(1.8 \mathrm{~kg}$ ) from the Agria $x$ Nif cross. Low plot yields $(\mathrm{kg})$ were from pollinated clones $208(2.2 \mathrm{~kg}), 209$ and $210(2.4 \mathrm{~kg})$.

Nif cultivar is a special genotype producing high level of flower, pollen, fruit and viable seed. Therefore it could be used as pollinator parent in our potato crosses. It could also be shown that male parent in each cross was Nif in our crossing and it acted differently for the characteristics measured. Some promising clone involving Nif with high means for the tuber number (figure 2), single tuber weight (g) (figure 3), plant yield (g) (figure 4) and plot yield (kg) (figure 5) are shown in Table 5.

Table 5. Superior clones involving Nif variety for the traits studied in the field trial.

\begin{tabular}{ll}
\hline Characteristics & Clone with decreasing order \\
\hline Plot yield $(\mathrm{kg})$ & $159,3,89,160,176$ \\
Plant yield $(\mathrm{g})$ & $3,184,159,160,195$ \\
Single tuber weight $(\mathrm{g})$ & $3,195,194,204,160$ \\
Tuber number & $184,176,174,90,153$ \\
Plant height $(\mathrm{cm})$ & $89,159,177,153,21$ \\
Stem number & 207 (open pollinated), 177, 159, 204, 163 \\
Leaf number & $177,164,89,179,153$ \\
\hline
\end{tabular}

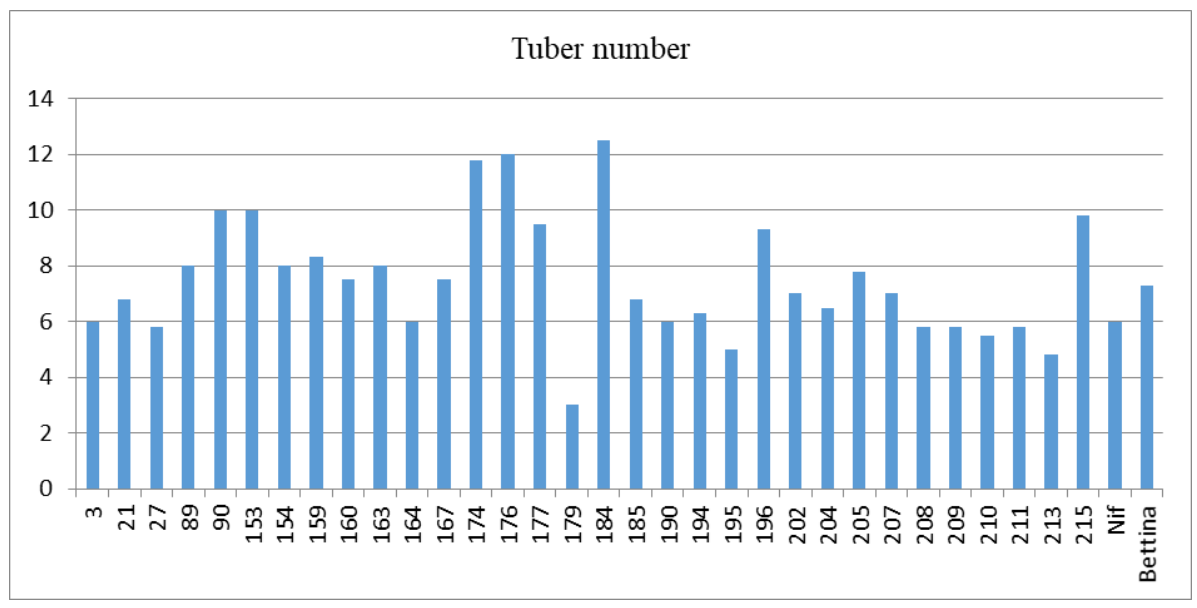

Figure 2. Histograms of the clones for tuber number 


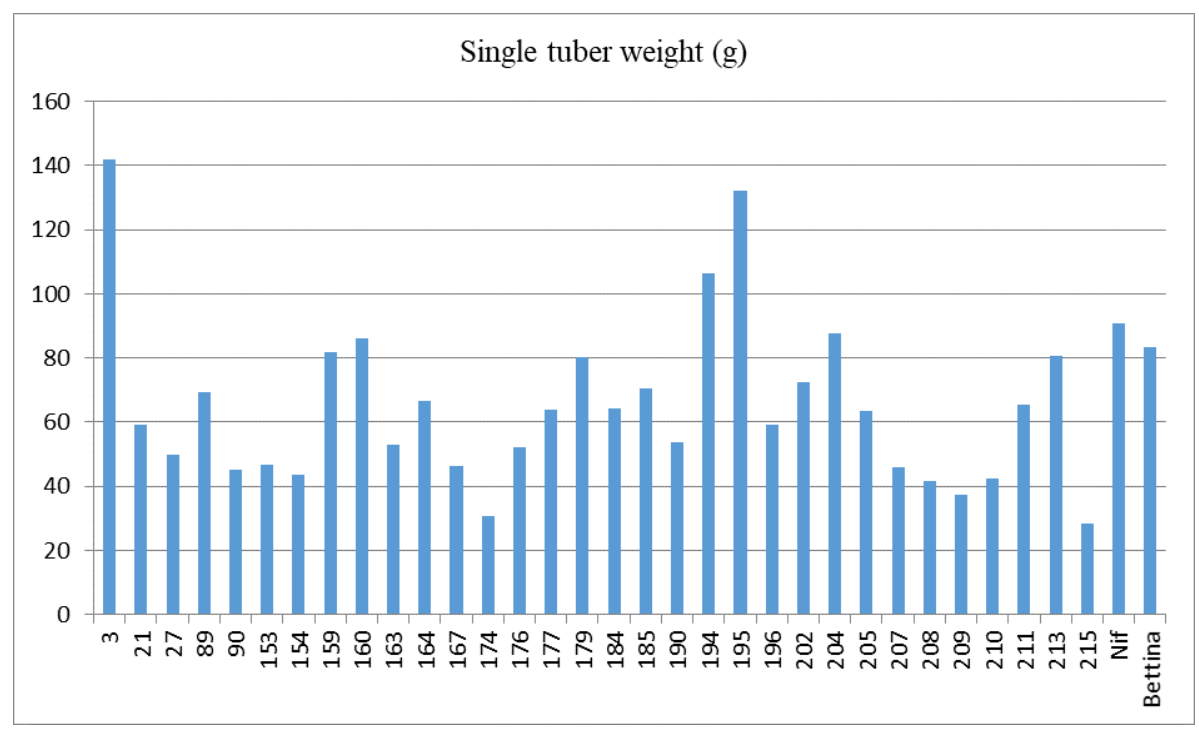

Figure 3. Histograms of the clones for single tuber weight (g)

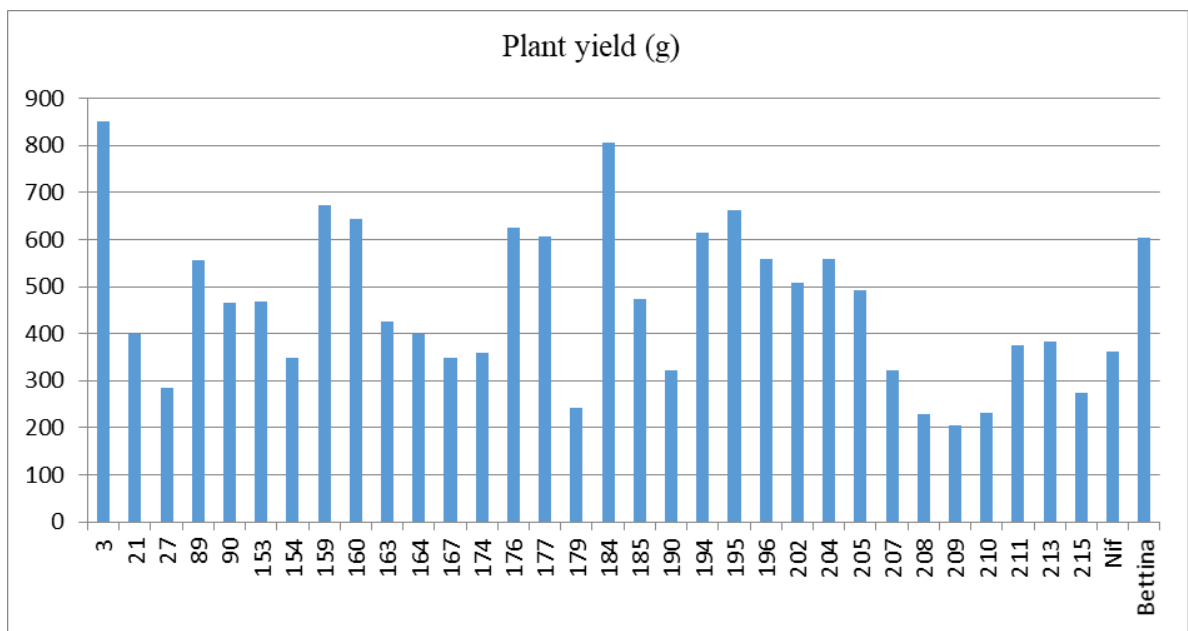

Figure 4. Histograms of the clones for plant yield (g)

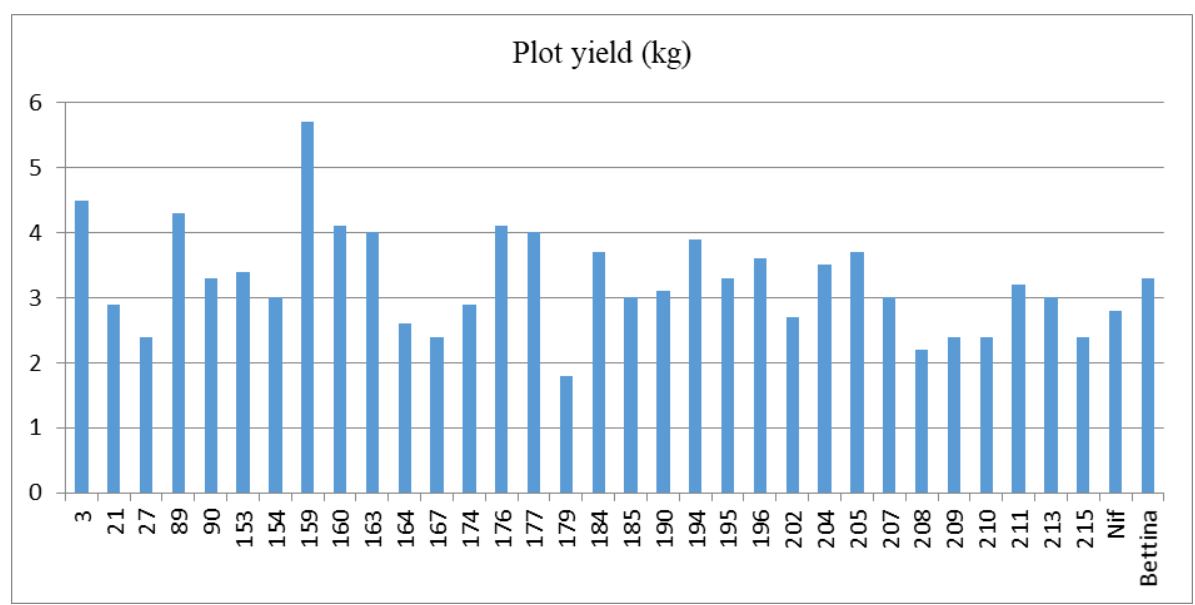

Figure 5. Histograms of the clones for plot yield $(\mathrm{kg})$ 


\section{CONCLUSIONS}

Conclusions drawn following result and discussion could be summarized as followings:

1. Several clones have over passed the controls (Nif and Bettina cultivar) for plant yield and plot yield.

2. Many clones with high means had cultivar Nif as male parent

3. Clones 3, 195, 160 had high single tuber weight and plant yield, clone 90 and clone 153 had high plant yield and tuber number

4. Clone 3, clone 159 had high means for single tuber weight, plant yield and plot yield

5. The following clones could be selected for the regional yield trial; 3, 21, 184, 185, 194, 195, 196, 202, 204 (Agria x Nif); 89, 90 (6/7 Clone x Nif); 205 (Juwel x Nif) and 153, 159, 160, 163, 164, 174, 176, 177 (Bettina $x$ Nif).

\section{ACKNOWLEDGEMENTS}

This study was supported by the Board of Ege University Scientific Research Projects (Report No: 2014ZRF-052). The authors would like to appreciate for the financial support.

\section{LITERATURE CITED}

Acikgoz, N., E. Ilker, A. Gokcol. 2004. Evaluation of biological research in computer. E.U. TOTEM, Publication No:2, Izmir (in Turkish).

Anonymous. 2016. Turkish Statistical Institute available at http//www.tuik.gov.tr (Accessed January 20, 2018)

Bulbul, M.K., M.E. Caliskan. 2014. Determination of yield and quality properties of some potato breeding lines in early and main product conditions. 11th Field Crops Congress, Canakkale (in Turkish).

Caliskan, C.F. and M.B. Yildirim. 1987. Phenotypic and genotypic correlations between certain traits of potato. DOGA 11: 291-293.
Cicek, N. 1987. Research on suitability of seed production technology and yield components in different matching type potato populations. Ph.D. Thesis, Ege University Institute of Science, Bornova

Ozkaynak, E. 2020. Development of PVX resistant potato breeding lines using marker-assisted selection. Turkish Journal of Field Crops 25(1): 66-73.

Kaya, C., T. Kara, A. Karakus, F. Sefaoglu. 2016. Determination of the performance of potato clones in advanced breeding stage under producer conditions. Journal of Field Crops Central Research Institute 25: 49-54 (in Turkish).

Ozturk, G. and Z. Yildirim. 2014. Heritability estimates of some quantitative traits in potatoes. Turk. J. Field Crops. 19(2): 262-267.

Yildirim, Z. and G. Ozturk. 2016. Field performances of some local potato cultivars from Eastern Turkey in the Aegean Region. Turk. J. Field Crops. 21(1): 97-100.

Steel, R.G.D. and J.H. Torrie. 1980. Principles and Procedures of Statistics, McGaw-Hill Book Company, Inc. N.Y.

Yildirim, M.B. 1977. Early Potato Breeding. Bitki Turkish Journal of Plant Science 4: 122-135 (in Turkish).

Yildirim, M.B., C.F. Caliskan. 1981. Evaluation of South American potato populations in terms of agricultural, physiological and quality. DOGA, 5: 249-257.

Yildirim, M.B., C.F. Caliskan, O. Caylak, Z. Yildirim. 1988. Obtaining of potato clones suitable for early and seed production technology by crossing. Project Final Report of Ege University (in Turkish).

Yildirim, M.B., C.F. Caliskan, O. Caylak, Z. Yildirim. 1991. Determination of adaptation capabilities of potato clones improved by crossbreeding to the Aegean Region. Project Final Report No: 89 ZRF / 015 (in Turkish).

Yildirim, M.B., N. Budak and N. Midikoglu. 1996. Genetic variability among the potato clones originated from Tuberosa x Andigena crosses. Turk. J. Field Crops. 1: 48-52.

Yildirim, M.B. and Z. Yildirim. 2002. Potato Farming, Potato Breeding, p.1-26 (in Turkish).

Yilmaz, G., N. Kandemir, Y. Yanar, Y.B. Karan, A. Kınay, S. Dokulen. 2014. Factors affecting crossing and cross seed production in different environments and periods in potato. 11. Field Crops Congress, 7-10 September, Canakkale. 